\title{
Super Leadership Approach, Organizational Culture and Performance Satisfaction to Improve Teachers' Performance (A Case Study in the Senior High School in the City of Makassar)
}

\author{
Ahmad Mappaenre \\ Faculty of Social Sciences, State University of Makassar \\ Makassar Gunungsari, 90222, Indonesia \\ E-mail: a.mappaenre@gmail.com
}

Received: August 31, 2013 Accepted: September 26, 2013 Published: November 29, 2013

doi:10.5296/ire.v2i1.4640 URL: http://dx.doi.org/10.5296/ire.v2i1.4640

\begin{abstract}
The purpose of this research is to review the implementation of super leadership characteristics by state senior high school headmasters in the Town of Makassar, culture of school organization, and teachers' performance satisfaction with the aim of observing its influence against teachers' performance both directly or indirectly through teachers' performance satisfaction. Type of the research is a survey study with causative quantitative approach. Sampling technique is by proportionate stratified random sampling. Data obtained through questionnaire instrument then analyzed using Structural Equation Modeling (SEM). The results of the research show: characteristics of headmasters' super leadership have significant influence against teachers' performance. Despite of the fact that super leadership has no direct effect on the teachers' performance satisfaction, it has significant indirect effect by its correlation with the organizational culture. This research also found that organizational culture has no direct effect against teachers' performance, but significantly, it has indirect effect on the teachers' performance satisfaction.
\end{abstract}

Keywords: Super leadership, organizational culture, performance satisfaction, teacher's teachers' performance 


\section{Introduction}

In such era of globalization, this is a time for the headmasters to play their role as super leader noting that the implementation of School Based Management (SBM) require headmasters, teachers and school staffs to be independent in the school management in order to meet educational purpose. Headmaster need to play as super leader by improving self leadership competence of every teacher that they are capable of leading themselves in performing their duty without tight supervision needed.

Motivated by the importance of headmaster's role to improve his leadership to be a super leader in the essence of helping his/her subordinates to become a self-leader, and the existence of school organization culture which is able to provide media for character building for school personals to keep enthusiastic, and have a stable performance satisfaction to meet both instructional and institutional purpose of education, so the researcher views the urgency to conduct research in this field.

From the mentioned background, the formulation of research problems are: (1) Lack of attention from headmasters to play their role as super leader in the effort of improving the capability of their subordinates (teachers) to lead their self (self -leadership) so that teachers' performance does not meet the expectation. (2) A firm school culture to foster teachers' motivation is not yet achieved; such condition does not reflect a conducive school culture to support the improvement of performance satisfaction and teachers' performance.

Research result is expected to contribute to the development of administrative science, especially leadership, school management, conduct and organizational culture, so it can be used as a fundamental base to help headmasters improve and develop their managerial skill through super leadership model. Therefore, teachers under leadership of super leader have wide capacity to do initiation, creation and policy upon their own performance which in turn will give positive effect on their performance. Similarly, organizational culture and teachers' performance satisfaction will be examined to see its linkages to teachers' performance. If this research gives significant result as predicted, it can be used as a model for headmasters and teachers to develop their own performance.

\section{Research Methodology}

\subsection{Type of the Research}

The type of this research is a survey research with causative quantitative approach;; unit of analysis used are State Senior High School headmaster in the city of Makassar which is being measured its super leadership skill, and Senior High School teachers which is examined their performance satisfaction and performance. And all of State Senior High Schools as institution are measured in terms of its organizational culture.

\subsection{Sampling Techniques}

It is obtained sample of 14 headmasters of 22 state schools, and 1.238 teachers from those 14 schools, it is selected 187 teachers to become sample based on proportionate stratified random sampling. This research has three exogenous variables namely super leadership of 


\section{Macrothink}

headmaster (X1), culture of school organization (X2), teachers' performance satisfaction (X3), and one endogenous variable that is teachers' performance (Y).

\subsection{Research Instruments}

Main instrument in this research is questionnaire. Another complementary instruments used are interview, observation, and documentation.

There are two phases of instrument development, namely compilation and instrument trial test. After trial testing and scoring, empirical validity of instrument is tested through the following analysis: point analysis or internal consistency test, construct validity test, and calculation of the instrumen reliability coefficient.

Instrument in the form of checklist used in this research is part of the technique in the questionnaire. The use of this technique is based on the e consideration that this research will need the involvement of huge number of respondents mainly teachers of all State Senior High Schools in the Town of Makassar in various locations. This technique allows more respondents to participate in a relatively short time. However, it should be noted that the result of this technique will always be limited, so it is also used interview as supporting technique to get more objective result.

\subsection{Data Analysis}

Data are analyzed using Structural Equation Modeling (SEM). Based on the conceptual framework and research design, this research uses SEM analysis technique through Analisis of Moment Structure (AMOS 20) program. This SEM technique allows researcher to test some exogenous variables, at the same time with several endogenous variables. The complete SEM modeling is basically comprised of Meansurement Model and Structural Model (Ferdinand, 2000).

\section{Research Findings}

It will be said good in the SEM analysis if the development of hypothetical model is theoretically supported by empirical data. Test result of the SEM analysis model in the last stage for Model-2 (Model-1 is not presented here) can be seen completely in Figure 3. 


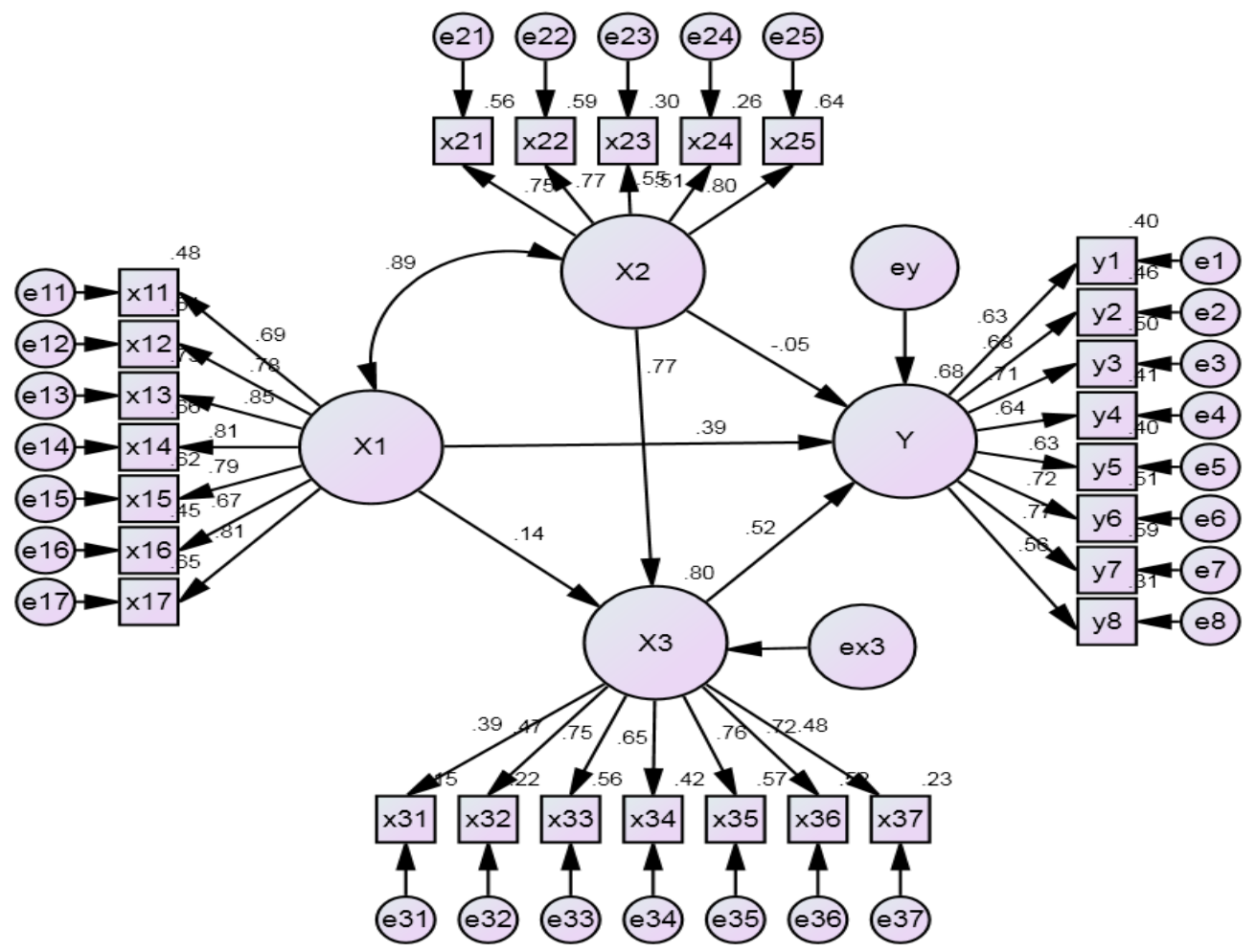

Figure 3 Test result Model-2 relationships between research variables

Result of model test based on Goodness of fit indices can be seen in the Table 1

Table 1. Criteria of evaluation Goodness of fit indices overall Model-2

\begin{tabular}{llll}
\hline Goodness of-fit index & Cut of Value & Model Result & Description \\
\hline CMIN/DF & $\leq 2.00$ & 2.577 & Does not meet the standards \\
NCP & $\leq 4.98$ & 501.514 & Does not meet the standards \\
RMSEA & $\leq 0.08$ & 0.092 & Meet the standards \\
NFI & $\geq 0.90$ & 0.746 & Does not meet the standards \\
IFI & $\leq 0.95$ & 0.827 & Meet the standards \\
RFI & $\leq 0.90$ & 0.719 & Does not meet the standards \\
CFI & $\geq 0.90$ & 0.825 & Meet the standards \\
\hline
\end{tabular}

Source: Result of data analysis using program of Amos 20 years 2012.

From the evaluation of Model-2, it shows that of seven criteria Goodness of fit indices, result with ideal criteria is not yet found, but this last model is more advanced compared to Model-2, as it is quite closer to the ideal model indicated by three results of model close to the criteria.

\section{Hypothesis Testing}

From Table 4.2, it is known that hyphotesis tested is acceptable if $p$ value smaller than 0.05 , indicating significant relationship between variables 
Table 2. Hypothesis testing

\begin{tabular}{lllllll}
\hline HIP & Independent & $\begin{array}{l}\text { Dependent } \\
\text { Variable }\end{array}$ & Variable & Direct Effect & & \\
\cline { 5 - 7 } & Standardize & CR & $p$ value & Description \\
\hline H1 & $\begin{array}{l}\text { Super } \\
\text { Leadership } \\
\text { (X1) }\end{array}$ & $\begin{array}{l}\text { Teachers' } \\
\text { Performance } \\
\text { (Y) }\end{array}$ & 0.390 & 2.226 & 0.026 & Significant \\
H2 & $\begin{array}{l}\text { Super } \\
\text { Leadership } \\
\text { (X1) }\end{array}$ & $\begin{array}{l}\text { Teachers' } \\
\text { Performance } \\
\text { Satisfaction } \\
\text { (X3) }\end{array}$ & 0.137 & 0.747 & 0.454 & Insignificant \\
H3 & $\begin{array}{l}\text { Organizational } \\
\text { Culture (X2) }\end{array}$ & $\begin{array}{l}\text { Teachers' } \\
\text { Performance } \\
\text { (Y) }\end{array}$ & -0.48 & 0.184 & 0.854 & Insignificant \\
H4 & $\begin{array}{l}\text { Organizational } \\
\text { Culture (X2) }\end{array}$ & $\begin{array}{l}\text { Teachers' } \\
\text { Performance } \\
\text { Satisfaction } \\
\text { (X3) }\end{array}$ & 0.768 & 3.470 & 0.001 & Significant \\
H5 & $\begin{array}{l}\text { Performance } \\
\text { Satisfaction } \\
\text { (X3) }\end{array}$ & $\begin{array}{l}\text { Teachers' } \\
\text { Performance } \\
\text { (Y) }\end{array}$ & 0.522 & 2.479 & 0.013 & Significant \\
\hline
\end{tabular}

Source: Result of data analysis using program of Amos 20 years 2012.

Table 2 informs that there are five hypotheses dealing with direct relationship between variables, they are: super leadership against teachers' performance, super leadership against teachers' performance satisfaction, organizational culture against teachers' performance, organizational culture against teachers' performance satisfaction and satisfaction against teachers' perfromance. Of the five hypotheses, only three are significant, and two others are insignificant.

Table 3 shows hypothesis of indirect relationship that is the effect of super leadership against teachers' performance through teachers' performance satisfaction. In fact, this relationship is not significant, while other linkage system that is the effect of school organizational culture against teachers' performance through teacher's performance satisfaction is significant.

Table 3. Hypothesis Testing (Indirect Effect)

\begin{tabular}{llllrll}
\hline HIP. & $\begin{array}{c}\text { Independent } \\
\text { Variable }\end{array}$ & $\begin{array}{c}\text { Intervening } \\
\text { Variable }\end{array}$ & $\begin{array}{c}\text { Dependent } \\
\text { Variable }\end{array}$ & $\begin{array}{c}\text { Standardize } \\
\text { Coefficient }\end{array}$ & P value & Description \\
\hline H6 & $\begin{array}{l}\text { Super } \\
\text { Leadership }\end{array}$ & $\begin{array}{l}\text { Teachers' } \\
\text { Performance } \\
\text { Satisfaction }\end{array}$ & $\begin{array}{l}\text { Teachers' } \\
\text { Performance }\end{array}$ & 0.072 & $(0.454)(0.013)$ & $\begin{array}{c}\text { In } \\
\text { significant }\end{array}$ \\
H7 & $\begin{array}{l}\text { School } \\
\text { Organizational } \\
\text { Culture }\end{array}$ & $\begin{array}{l}\text { Teachers' } \\
\text { Performance } \\
\text { Satisfaction }\end{array}$ & Teachers' & 0.401 & $(0.001)(0.013)$ & Significant \\
\hline
\end{tabular}

Source: Result of data analysis using program of Amos 20 years 2012. 
From the relationship between variables, the following are possible interpretations:

\section{Hypothesis 1}

Hypothesis 1 in this research states that super leadership shows a positive correlation with teachers' performance.

\section{Hypothesis 2}

Hypothesis 2 in this research states that super leadership correlates with teachers' performance satisfaction. Research findings showing CR value 0.749 and $p$-value 0.454 shows that $p$-value $>0.05$. Therefore, hypothesis stating super leadership effect on teachers' performance satisfaction is not valid.

\section{Hypothesis 3}

Hypothesis 3 states that school organizational culture effects on teachers' performance. Research findings showing CR value -0.184 and $p$-value 0.854 is higher than 0.05 . Therefore, hypothesis stating super leadership effect on teachers' performance is not valid.

\section{Hypothesis 4}

Hypothesis 4 in this research states that organizational culture shows a positive effect on teachers' performance satisfaction. With $\mathrm{CR}$ value 3.470 and $p$-value 0.001 , it proved that regression coefficient obtained is different from zero and $p$-value $<0.05$. Therefore, hypothesis stating organizational culture effect on teachers'performance satisfaction is valid.

\section{Hypothesis 5}

Hypothesis 5 in this research states that teachers' performance satisfaction correlates with teachers' performance. Research findings showing CR value 2.479 and $p$-value 0.013 proved that regression coefficient obtained is different from zero and $p$-value $<0.05$. Therefore, hypothesis stating teachers' performance satisfaction effect on teachers' performance is valid.

\section{Hypothesis 6}

Hypothesis 6 states super leadership correlates with teachers' performance through teachers' performance satisfaction. Research findings showing coefficient value 0.047 and $p$-value 0 , 455 and 0.017 , proved that $p$-value $>0.05$. Therefore, hypothesis stating super leadership effect on teachers' performance through teachers' performance satisfaction is not valid.

\section{Hypothesis 7}

Hypothesis 7 states that organizational culture correlates with teachers' performance through teachers' performance satisfaction. Research findings showing coefficient value 0.072 and $p$-value 0.013 it proved that regression coefficient obtained is different from zero and $p$-value $<0.05$. Therefore, hypothesis stating organizational culture effect on teachers' performance through teachers' performance satisfaction is valid. 


\section{Discussion}

Hypothetical result based on the SEM Analysis shows that super leadership of headmasters of State Senior High Schools in Makassar has significant effect on teachers' performance. This finding supports a research by Elloy (2005) which showed that groups led by a super leader supervisor have positive effect on the employee's framework in certain media of self-management. This finding is also in line with the research by Zulpen (2005) and Wuviani and Via (2005) that found significant correlation between leadership of headmaster and teachers' performance.

This finding showing theoretical implication that super leadership model is a leadership model concentrating on the empowerment of subordinat self-leadership (Manz and Sims, 2001) is strengthened by this finding.

Relationship between headmaster's super leadership with teachers' performance satisfaction shows coefficient of 0.14 and in fact, it is not significant. This indicates that headmaster's super leadership has no direct effect on the teachers' performance satisfaction. However, based on its relationship with school organizational culture, apparently it has a significant and strong correlation that is 0.89 . Meanwhile, school organizational culture shows a significant and firm correlation against performance, with coefficient value 0.77 . This means that super leadership of State Senior High School headmaster in Makassar does not directly effect on teachers' performance satisfaction, but it has a direct effect through its correlation with school organizational culture.

This finding which states insignificant correlation between super leadership and teachers' performance satisfaction is not in line with research by Mappaenre (1999) found positive correlation between leadership effectiveness and performance satisfaction in the same research location fourteen years ago.

Correlation between school organizational culture and teachers' performance shows statistic coefficient -0.48 , which is insignificant. This means that current condition of school organizational culture tends to reduce teachers' performance. However, it can be seen that school organizational culture as discussed above, has significant and strong effect (0.77) on the teachers' performance satisfaction, while teachers' performance satisfaction directly and significantly correlates with teachers' performance with coefficient 0.52 , relatively strong. These research findings reveal that school organizational culture does not directly affect teachers' performance, but it has a indirect effect through teachers' performance satisfaction.

This finding in which direct correlation between organizational culture and teachers' performance is insignificant is not in line with a research by Mulyadi (2003), Sukmalana. Those researches found that organizational culture significantly and positively effect on the organization's performance. These findings are not in line with theory of consistency developed by Osgood \&Tannenbaum (1955), and Rosensberg (1956).

Research findings state that teachers' performance satisfaction correlates with teachers' performance. Teachers' performance satisfaction has a direct positive correlation against the performance. With coefficient value 0.522 , it shows that the higher teachers' performance 
satisfaction rate the higher their performance. Implication obtained from the findings of this research that teachers' performance satisfaction (salary, challenging job, promotional opportunity, colleague, supervisor, leader's policy and working environment) has a positive effect on teachers' performance (quality and quantity of work, teacher's integrity, teacher's competence, initiative, teacher's commitment in performing the duty, communication, discipline and development).

Determining factors having great contribution on the performance satisfaction variable are supervisor and leader's policy, while the lowest support is challenging job and wage. This result is in line with the opinion of Luthan (2006) that stated a newest research finding that support causative relationship between performance satisfaction and employee's performance, and apparently satisfaction is more influential to performance rather than vice versa.

\section{Conclusion}

Super leadership of State Senior High School di the Town of Makassar has significant effect on the teachers' performance. Supporting factors of super leadership give positive contributions such as: Self-leadership skill gives a role model of self-leadership for teacher, motivates teachers to determine self-advice to get better performance, develops positive mindset, develops self-leadership skill both individually or in a team, has a firm and gentle attitude as principle and encourage self-leadership culture.

Headmasters' super leadership of State School in Makassar does not correlate directly with teachers' performance satisfaction, but it shows significant effect on organizational culture. Organizational culture of State School in Makassar does not correlate directly with teachers' performance, but it shows significant effect on teachers' performance satisfaction.

Organizational culture factors such as norm, value, belief, philosophy and climate do not contribute directly to the development of teachers' performance, but significantly it affects on organizational culture building to foster teachers' performance satisfaction.

Performance satisfaction of state school teachers in the Town of Makassar has significant effect on the teachers' performance. This results show that teachers' performance satisfaction which is determined by salary, job/duty, promotion, colleague, supervisor, policy and environment contribute positively to the improvement of teachers' performance which cover quality and quantity, integrity, competence, initiative, commitment, communication, discipline and development of teacher's competence.

Super leadership can have direct effect on teachers' performance satisfaction if weak components of manifest variable of super leadership itself; self-leadership skill and firmness and gentleness are fixed. This can be realized through educational and training programs for school headmasters.

School organizational culture can improve teachers' performance directly, by improving the weak components in the organizational culture that are reliance among members and organizational philosophy of school. 


\section{References}

Adi, I. R. (2008). As a Community Development Community Intervention Efforts for Community Empowerment. Jakarta. Rajagrafindo Persada.

Anonim. (2011). 70 Weak Percent Principal Managerial and Supervision. Retrieved from www.pikiran-com

Antonio, M. S. (2009). Muhammad Was The Super Leadership Super Manager. Jakarta: PROm Centre \& Tazkia Publishing.

Baharudin, T. (2007). Brainware Leadership Mastery. Jakarta: Elex Media Komputindo.

Bass, B. M., \& dan Avolio, B. J. 1(993). Transformational Leadersihip and Organizational Culture. Public Administration Querterly, 17(1), 112-17.

Bennis, W., \& Townsend, R. (1998). Reinventing Leadership (Menciptakan Kembali Kepemimpinan). Batam Centre: Interaksara.

Cook, S., \& dan Macaulay, S. (1996). Perfect Empowerment: Empowerment of the Right. Jakarta: Elex Media Computindo.

Elloy, D. F. (2006). Superleader Behaviors And Self-Managed Work Teams: Perceptions Of Supervisory Behaviors, Satisfactions With Growth, And Team Functions. Journal of Business \& Economics Research, 4(12), 97-102.

Gibson, J. L., Ivancevich, J. M., \& Onnelly, J. H. (1996). Orgnisasi: Perilaku, Struktur, Proses. Jakarta: Binarupa Aksara.

Greenberg, J. dan Baron, \& Robert, A. (2003). Behavior in Organizations. New Jersey: Prentice-Hall.

Keban, Y. T. (2008). Six Dimensions of Strategic Public Administration Concepts, Theories and issues. Yogyakarta: Penerbit Gava Media.

Komariah, Aan dan T. (2008). Visionary Leadership Towards Effective Schools. Jakarta: Bumi Aksara.

Luthans, F. (2006). Organizational Behavior. Yogyakarta: Penrbit Andi yogyakarta.

Manz, C. C. dan Sims, \& Henry, P. (2001). The New SuperLeadership: Leading Other to Themselves. San Francisco: Berret Koehler Publisher, Inc.

Mappaenre, A. (1999). Efektivitas Kepemimpinan Kepala SMU Negeri dan Kepuasan Kerja Guru (Kasus di Kotamadya Ujung Pandang). (Thesis). Program Pascasarjana Universitas Hasanuddin.

Maria, S. (2004). Pengaruh Kompetensi Profesional dan Iklim Organisasi terhadap Kinerja Dosen (Studi Kasus pada Akademi Keperawatan Budi Luhur dan Ahmad Yani Ciamis).

Mulyadi, D. (2003). Faktor-Faktor Strategik yang Mempengaruhi Pengembangan Kinerja Dosen PTK (Studi tentang Perilaku Kepemimpinan, Budaya Organisasi dan Manajemen 
Mutu terhadap Kinerja Dosen STIA LAN). Disertasi. UPI Bandung. Not published.

Mustopadidjaja. (2000). Government Performance Measurement. Jakarta. Institute of Public Administration.

Riduwan. dan Kuncoro, \& Ahmad, E. (2007). How to Use and Wear Path Analysis. Bandung: Alfabeta.

Ruky, A. S. (2002). Performance Management System. Jakarta: Gramedia Pustaka Utama.

Robbins, S. P. (1996). Organizational Behavior Volume 2. Pujaatmaka translation. 1996. Jakarta: PT. Prenhallindo.

Robbins, S. P. (2002). Principles of organizational behavior. translated Parsaeian and. Jakarta: publisher grants.

Rohiat. (2009). Elementary-School Management Theory and Practice. Bandung: Refika Aditama.

Susanto, A. B. (2009). Super Leadership: Leading Others to Lead. Jakarta: Gramedia Pustaka Utama.

Wexley, K. N., \& Yukl, G. A. (1977). Organizational behavior and personnel psychology. RD Irwin.

Wibowo. (2011). Organizational Culture (A need to improve the long-term performance). Jakarta: Rajawali Pers.

Wuviani, V. (2005). Faktor-Faktor yang Mempengaruhi Kinerja Guru (Studi tentang Pengaruh Kualifikasi, Motivasi Kerja Guru dan Kepemimpinan Kepala Sekolah terhadap Kinerja Guru SMAN di Kota Bandung). Tesis. Program Pascasarjana UPI. not Published

Yukl, G. (2005). Leadership in Organisasi. Jakarta: PT Indeks Kelompok Gramedia.

Zulpen. (2005). Kontribusi Perilaku Kepemimpinan Kepala Sekolah dan Pelatihan Guru terhadap Kinerja Mengajarnya (Studi Deskriptif Analisis di SMAN Kota Pekan Baru). Tesis not Published. Bandung: Program Pascasarjana-UPI.

\section{Copyright Disclaimer}

Copyright reserved by the authors.

This article is an open-access article distributed under the terms and conditions of the Creative Commons Attribution license (http://creativecommons.org/licenses/by/3.0/). 